\title{
New stratigraphic insights in the 'Late Jurassic' of the Southern Central North Sea Graben and Terschelling Basin (Dutch Offshore) and related exploration potential
}

\section{A. Abbink*, H.F. Mijnlieff, D.K. Munsterman \& R.M.C.H. Verreussel}

TN0 B\&0, Geological Survey of the Netherlands, P.0. Box 80015, NL-3508 TA Utrecht, the Netherlands

* Corresponding author. Email: oscar.abbink@tno.nl

Manuscript received: December 2005; accepted: September 2006

\begin{abstract}
Middle Jurassic - Early Cretaceous strata are a target for oil and gas exploration in the Dutch offshore. During the initial stages of the 'Late Jurassic' offshore exploration, various oil fields and a few gas fields were discovered of which only one, the F3-FB field, proved to be economically viable. In the Northern Offshore of the Netherlands, latest Middle Jurassic (Callovian) - earliest Cretaceous (Ryazanian) strata are mostly limited to the Dutch Central Graben and Terschelling basins. Outside the Dutch Central Graben and the Terschelling Basin only thin veneers of these strata occur on the fringing highs such as the Schill Grund High and the Step Graben. The geology of this non-marine to shallow marine succession is complex. The combination of lateral facies changes, repetitive log and facies characteristics in time, sea-level and climate changes, salt tectonics and structural compartmentalisation hamper straightforward seismic interpretation and log correlation. The large number of lithostratigraphic units defined in the Stratigraphic Nomenclature of the Netherlands illustrates the complexity of this time-interval.

In recent years, new biostratigraphic techniques and newly acquired stratigraphic data led to the identification of a series of events which can be related to the tectonic, climatic, environmental and stratigraphic development of the 'Late Jurassic' in the Dutch Central Graben and Terschelling basins. Based on these data, three stratigraphic sequences can be recognized. Sequence 1 (Callovian - earliest Kimmeridgian) records the initiation of the Dutch Central Graben, Sequence 2 (early Kimmeridgian - early Portlandian) that of the initiation of the Terschelling Basin. During sequence 3 (late Portlandian - Ryazanian) the Dutch offshore was draped by a regional transgression. These insights have directly impact on the exploration potential, which is discussed in two play concepts. The first is a strat-trap play in the fluvial/paralic sediments of Sequence 1 in the lows between the graben boundary and salt domes. The second example is the Spiculite play, which comprises a bioclastic sandstone reservoir at the top of a dome with a 4-way dip closure. These two examples highlight the necessity of understanding the paleoenvironment and geography for assessing the future exploration potential.
\end{abstract}

Keywords: Dutch offshore, Late Jurassic, stratigraphy, paralic \& shallow marine deposits, stratigraphic trap, spiculite, hydrocarbons, exploration

\section{Introduction}

In the Northern 0ffshore of the Netherlands territorial waters the distribution of the Upper Jurassic - Early Cretaceous strata, more specifically of the Schieland and Scruff Groups, is limited to the Dutch Central Graben and Terschelling Basin (Figure 1). Outside the Dutch Central Graben and the Terschelling Basin, only thin veneers of these strata occur on fringing highs such as the Schill Grund High and the Step Graben.
Late Jurassic - Early Cretaceous strata are a target for oil and gas exploration. In the early days of the Dutch offshore exploration history various oil fields and some gas fields were discovered. Only the F3-FB field proved to be economic. Other oil fields, such as F14-A an F17-FA for example, have been, until now, not economic due to complex reservoir architecture predicting a low recovery. Interest in the exploration of the Late Jurassic - Early Cretaceous play ceased in the 1980's. Renewed interest in this play came in the 7th round (1989) 


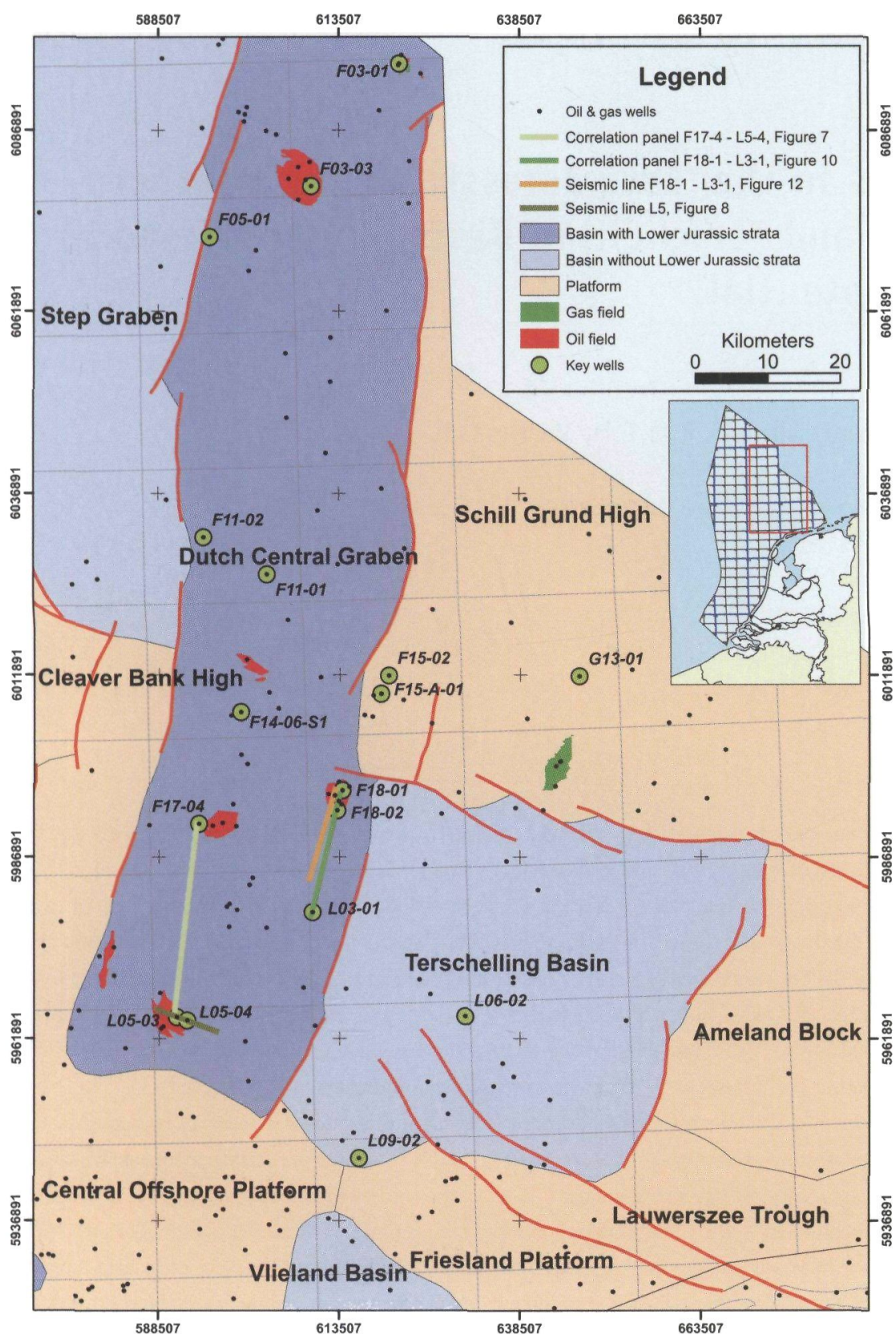

Fig. 1. Location map and general overview of the tectonic elements of the northern Dutch offshore including the Central Graben, Step Graben and the Terschelling Basin, and the location of the correlation lines (Figs 7 and 10) and the location of the seismic lines (Figs 8 and 11).

when the 'Friese Front restricted area' was opened for exploration. Numerous wells were drilled with the Late Jurassic Early Cretaceous as target but few proved to be successful. The discovery wells L06-02 and G16-01 found gas accumulations in the Jurassic-Cretaceous strata but were at that time too small for development.

The estimated total Stock Tank 0il Initially In Place (STOIIP) in stranded fields amounts to $55 \mathrm{MMm}^{3}$. The reserves, however, remain low. A rough estimate is in the order of $5-7 \mathrm{MMm}^{3}$. The public domain data of the 'Late Jurassic' discoveries is summarized in Table 1.

However, recently due to better understanding of the complex geology of the Late Jurassic - Early Cretaceous, interest in this play was renewed. This paper aims (1) to summarize and reference the Late Jurassic - Early Cretaceous stratigraphic information in the public domain, (2) to compile a comprehensive and integrated stratigraphic framework and (3) to present two examples of potential plays in the Late Jurassic. The first example of the latter aim is a speculative paralic/ fluvial Callovian-0xfordian strat-trap play in the centre of the rim synclines. The second example is the Spiculite Play.

\section{Database and methodology}

There are about 150 released wells in the study area. In the past, TNO has studied most of these wells biostratigraphically. This dataset forms the basis for the present study. In addition, sedimentological, lithological and (limited) seismic information contributed to the used dataset. 
Table 1. Summary of Upper Jurassic - Lower Cretaceous oil and gas fields in the study area.

\begin{tabular}{|c|c|c|c|c|c|c|}
\hline Field & Discovery well & Discovery date & Stratigraphy & Sequence & Fluid & Remark \\
\hline B18-FA & B18-03 & 1982 & Lower Graben Fm. & Seq. 1 & Oil & stranded \\
\hline F03-FA & F03-01 (type well) (F03-08) & $1971(1982)$ & Lower Graben Fm. \&. Scruff Greensand & Seq. $1 \& 3$ & Gas & stranded \\
\hline F03-FB & F03-03 (F3-FB-101) (type well) & $1974(1992)$ & Lower, Middle and Upper Graben Fm. & Seq. 1 & Oil \& gas & producing \\
\hline F03-FC & F03-07 & 1981 & Scruff Greensand & Seq. 1 & Oil & stranded \\
\hline F14-A & F14-05 & 1986 & Lower Graben Fm. & Seq. 1 & Oil & stranded \\
\hline F17-FA & F17-03 & 1982 & Schieland Group & Seq. 1 & Oil \& gas & stranded \\
\hline F17-FB & F17-04 (type well) & 1982 & Schieland Group & Seq. 1 & Oil & stranded \\
\hline F18-FA & F18-01 (type well) & 1970 & Schieland Group & Seq. 2 & Oil & stranded \\
\hline G16-FA & G16-01 & 1985 & Scruff/Zechstein & Seq. $3 \& 1$ & Gas & Production planned \\
\hline L01-FB & L01-03 & 1985 & Schieland Group & Seq. 1 & Oil & stranded \\
\hline L05-FA & L05-05 & 1988 & Terschelling Sandstone Mb. & Seq. 1 & Oil & stranded \\
\hline L06-FA & L06-02 & 1990 & Terschelling Sandstone Mb. & Seq. 2 & Gas & Production planned \\
\hline
\end{tabular}

\section{Age interpretation}

The age interpretations are based on palynology. Due to the dominance of clastic sediments and the shallow to non-marine character of the sediments, other fossil groups are of limited use. The palynostratigraphy is according to Riding \& Thomas (1992), Duxbury et al. (1999) and Herngreen et al. (2000) for the dinoflagellate cysts, and according to Abbink (1998) and Herngreen et al. (2000) for the sporomorphs.

\section{Paleoenvironmental and paleoclimatic interpretations}

The majority of the paleoenvironmental interpretations are based on palynological data. Based on a paleoecological model, several Sporomorph EcoGroups (SEGs) can be recognized (for further explanation see Abbink, 1998; Abbink 2004a, b). The SEG model allows the recognition of sea-level fluctuations and climate, based on palynology, in the very shallow to nonmarine environments of the Late Jurassic (Abbink, 1998; Abbink et al., 2004a and b). Support for the age interpretations is based on the detailed climate reconstruction by Abbink et al. (2001). This reconstruction recognizes a number of relatively distinct climate shifts expressed by the quantitative sporomorph data. These shifts form the boundaries of specific climate intervals and are considered isochronous for the Dutch territory.

In addition, core descriptions and, if present, ichnofossil descriptions were used (Werver, 1996, 1997).

\section{Sea-level fluctuations}

The common acceptance of sequence stratigraphic concepts has led to a major role for sea-level changes in describing and explaining basin development. After the publication by Haq et al. (1988) several studies were conducted concerning the sealevel fluctuations of the Callovian - Ryazanian in Northwest
Europe. Partington et al. (1993) defined and calibrated maximum flooding surfaces across the North Sea basin. Rioult et al. (1991), DeGraciansky et al. (1999) and Jacquin et al. (1999) revised the Haq et al. (1988) curve.

In our study, we have followed the concepts of Vail (e.g. Vail et al., 1991) complemented with the MFS scheme by Partington et al. (1993). The SEG model (Abbink et al., 2004a, b) allows the correlation of MFS into terrestrial settings. Together with the high resolution climate shifts, the MFS form a reliable and consistent correlation tool. An overview of the followed stratigraphy is given in Figure 2.

\section{‘Late Jurassic’ stratigraphic sequences}

The presence of three well recognizable unconformities or their correlatable conformities has led to the recognition of three major stratigraphic sequences in the 'Late Jurassic' interval and one in the overlying Early Cretaceous interval. These sequences, if preserved, are identifiable throughout the study area. A schematic diagram of the four sequences with their key lithostratigraphic units is given in Figure 3. The lithostratigraphy (Van Adrichem Boogaert \& Kouwe, 1993), with matching colours, is given in Table 2. Sequence 4 (Valanginian and younger) is not discussed in detail, as it falls outside the 'Late Jurassic' interval.

\section{Late Jurassic - earliest Cretaceous tectonic activity}

Large scale continental movements occurred throughout the Middle and Late Jurassic. These movements were related to the break-up of Pangea. For the North Sea region, several, so called Cimmerian, tectonic phases, are described (e.g. Ziegler, 1990), which significantly affected the Northern Dutch Offshore (Herngreen \& Wong, 1989). During the Middle Jurassic, a doming event in the North Sea occurred (Mid Cimmerian phase). The southern extension of this Central North Sea Dome reached 


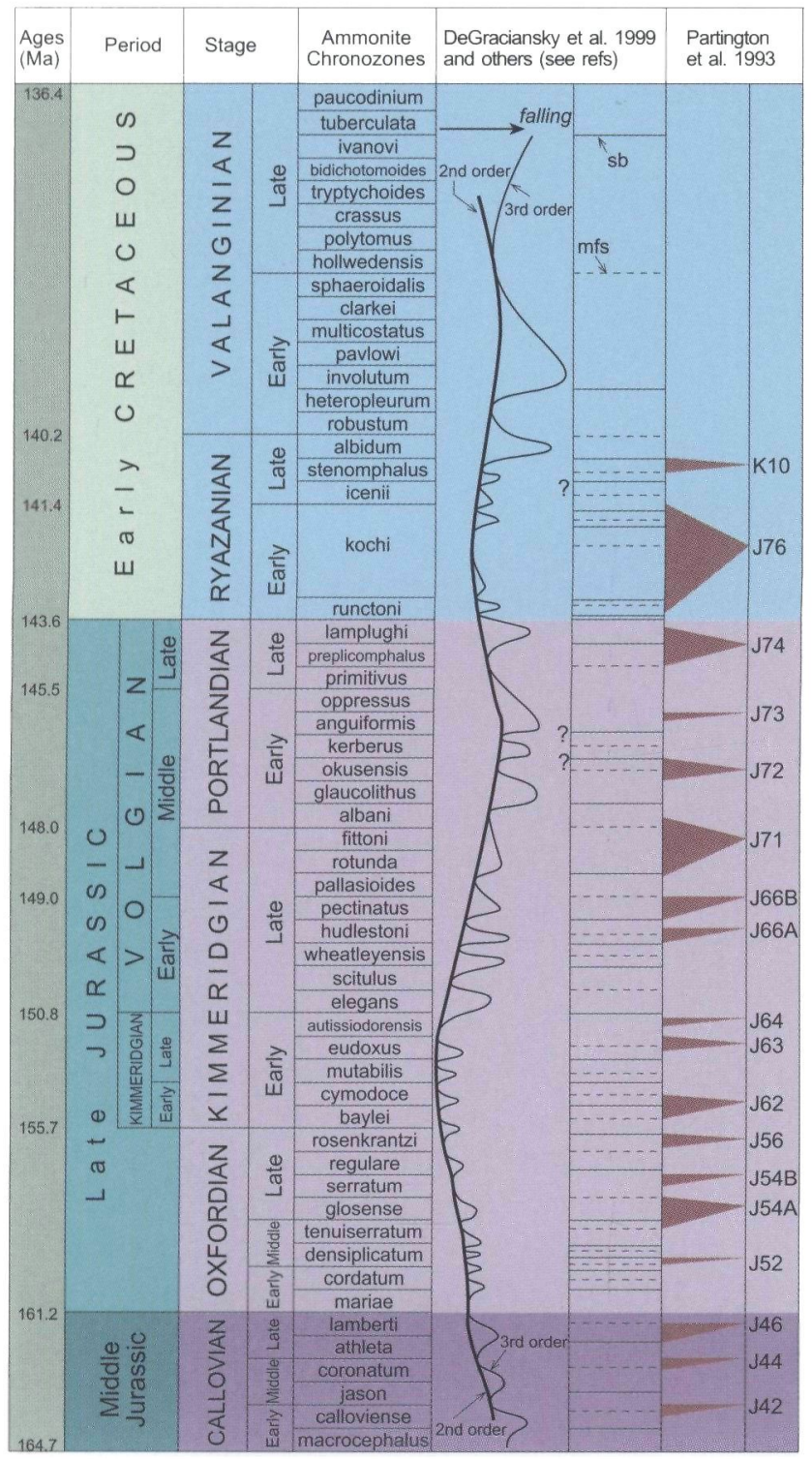

Fig. 2. Callovian - Valanginian stratigraphy including the absolute ages, stages and ammonite chronozones after Gradstein et al. (2005), sealevel curve (DeGraciansky et al. 1999) and MFS and maximum extent of corresponding condensed horizon (red triangles) of the J-sequences of Partington et al. (1993). See text for further explanation.

the Dutch offshore, resulting in erosion and non-deposition during the Middle Jurassic (Underhill \& Partington, 1993). This doming event caused the hiatus between the 'Late Jurassic', and underlying Early Jurassic or older strata in the Northern Dutch Offshore.

After deflation of the Mid North Sea Dome, a whole series of basins came into existence, collectively referred to as the Central Graben ranging from Norway in the north to the Netherlands in the south. Subsidence of the Dutch Central Graben led to an overall, stepwise, transgression coming from the North throughout the 'Late Jurassic'. The tectonic activity in the 'Late Jurassic' (Late Cimmerian phase) affected sedimentation patterns in the Central Graben (Ziegler, 1991;
Partington et al., 1993, this paper). The presence of a Late Cimmerian Unconformity is frequently suggested, and it is linked with the base of the Cretaceous ("base Cretaceous unconformity'). However, several tectonic pulses can be recognized in the Dutch Central Graben, often indicated by unconformities or hiatuses. Based on our results, three major tectonic pulses are present which caused the boundaries between the recognized sequences. These pulses are suggested to be related to the rift process in the North Atlantic area (Ziegler, 1991).

\section{Sequence 1: Middle Callovian - earliest Kimmeridgian (Fig. 4)}

The base corresponds to the inception of the Dutch Central Graben and varies from Middle Callovian in the north (F3 area) to earliest 0xfordian in the southernmost part (L05 area). Shallow marine deposits occur in the northern part of the DCG, while in the southern part (L05 area) non-marine deposits prevail. Apart from the Dutch Central Graben, most Dutch basins such as the Terschelling Basin, the Vlieland Basin, and the Broad Fourteens, West, and Central Netherlands Basins in the south experienced no sedimentation at this time. The top of this sequence is marked by an unconformity in the early Kimmeridgian (Mutabilis Ammonite Chronozone), caused by local uplift, at least in the south-western part of the Dutch Central Graben.

Within this Sequence, the Callovian/0xfordian boundary is present. This boundary is expressed by the continent-wide $\mathrm{J} 46$ MFS which coincides with the base of the Middle Graben Fm. A characteristic coal doublet or triplet is present in this interval. Another MFS, the Late 0xfordian J54 MFS forms the base Kimmeridge Clay Fm. in F9/F6/F3 blocks. The Early Oxfordian Densiplicatum climate shift is present (Middle Graben Fm.). The palynological data of the depicted type well F03-03, unfortunately, is not suitable for applying the SEG model (Fig. 4). However, the climate shift is inferred from many other wells such as F17-04, L05-03, L05-04 (Abbink et al., 2001), as well as many un-published wells (TNO in-house information). For detailed climate information of this time interval, we refer to Abbink et al., 2001.

\section{Sequence 2: Early Kimmeridgian - Early Portlandian (Fig. 5)}

The base of Sequence 2 is dated as Early Kimmeridgian (Mutabilis Ammonite Chronozone) and the top as early Early Portlandian (Anguiformis Ammonite Chronozone). The start of this sequence involved decreased sedimentation rates in the northern part of the Dutch Central Graben while at the same time, in the southeast, the Terschelling Basin came into existence (Figs 3, 5). 


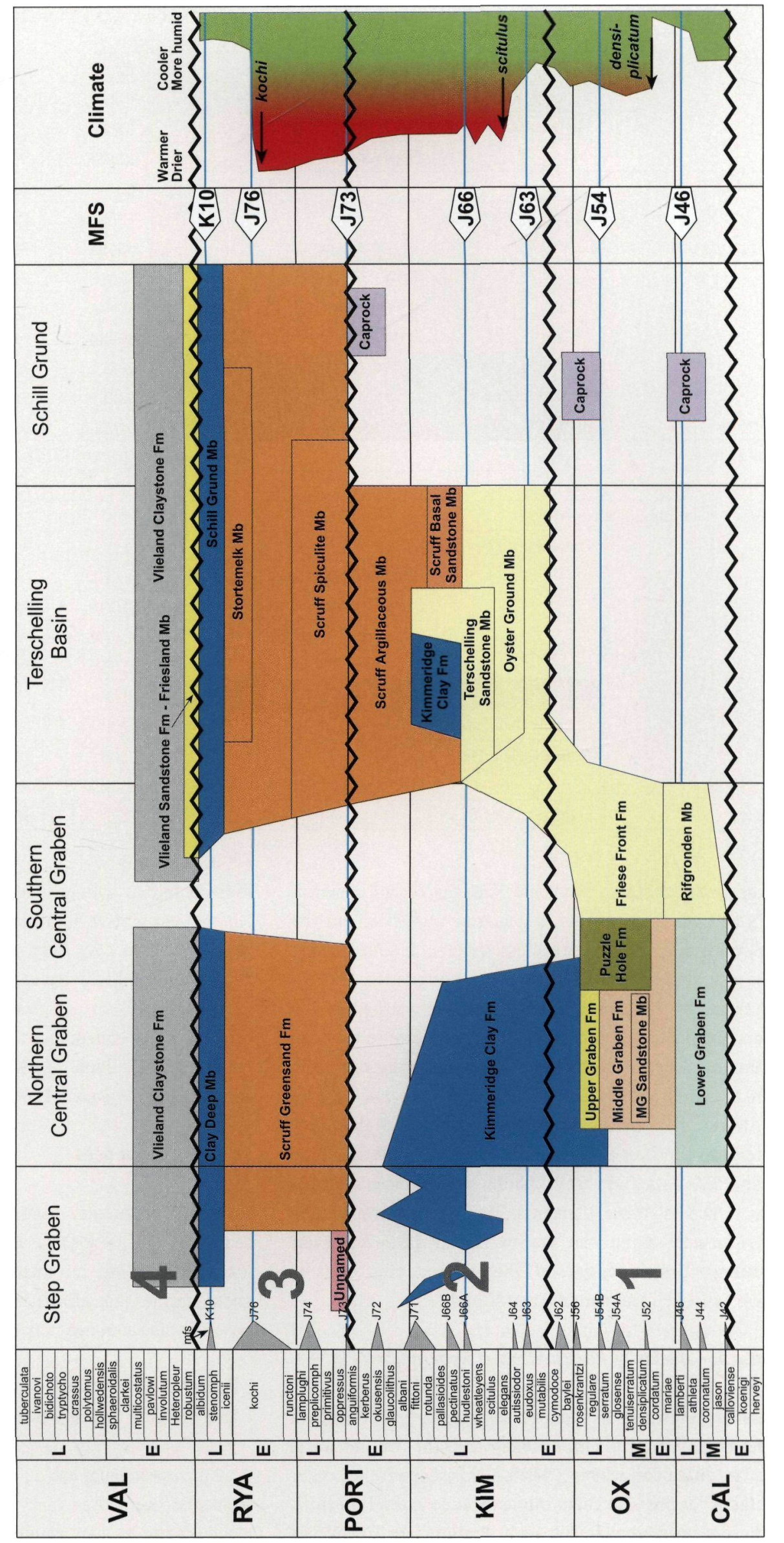

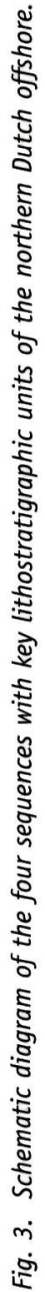


Table 2. 'Late Jurassic' lithostratigraphic subdivision, including abbreviations and type sections. Colours correspond to the formation colours in Figure 3.

\begin{tabular}{|c|c|c|c|c|c|}
\hline \multirow[t]{4}{*}{ Rijnland Group } & & $\therefore$ & $\mathrm{KN}$ & Vlieland 0ost-1 & $1522 m-2246 m$ \\
\hline & Vlieland Claystone & & KNNC & Vlieland 0ost-1 & $1650 m-220 m$ \\
\hline & Vlieland Sandstone & & KNNS & Vlieland 0ost-1 & $2200 m-2246 m$ \\
\hline & & Friesland $\mathrm{Mb}$ & KNNSF & Vlieland Oost-1 & $2200 m-2246 m$ \\
\hline \multirow[t]{9}{*}{ Scruff Group } & & & SG & F03-3 & $1682 m-2547 m$ \\
\hline & Scruff Greensand F & & SGGS & F15-2 & $3021 m-3276 m$ \\
\hline & & Stortemelk Mb & SGGSS & F18-2 & $2079 m-2105 m$ \\
\hline & & Scruff Spiculite Mb & SGGSP & F18-1 & $2193 m-2230 m$ \\
\hline & & Scruff Argillaceous Mb & SGGSA & F15-2 & $3065 m-3246 m$ \\
\hline & & Scruff Basal Sandstone Mb & SGGSB & F15-2 & $3246 m-3267 m$ \\
\hline & Kimmeridge Clay F & & SGKI & F03-3 & $1780 m-2547 m$ \\
\hline & & Schill Grund Mb & SGKIS & F18-2 & $2042 m-2079 m$ \\
\hline & & Clay Deep Mb & SGKIC & B18-2 & $2225 m-2357 m$ \\
\hline \multicolumn{3}{|l|}{ Schieland Group } & SL & Nieuwerkerk-1 & $1052 m-1942 m$ \\
\hline & \multicolumn{2}{|c|}{ Delfland Subgroup } & SLD & $\mathrm{F} 03-3$ & $2547 m-3652 m$ \\
\hline & \multicolumn{2}{|c|}{ Central Graben Subgroup } & SLC & F03-3 & $2547 m-3652 m$ \\
\hline & \multicolumn{2}{|l|}{ Friese Front Fm } & SLCF & F18-2 & $2440 m-2734 m$ \\
\hline & & Terschelling Sandstone Mb & SLCFT & L09-2 & $3028 m-3054 m$ \\
\hline & & Oyster Ground Claystone Mb & SLCF0 & F18-2 & $2440 m-2512 m$ \\
\hline & & 'Main Friese Front Mb' & SLCFM & & \\
\hline & & Rifgronden $\mathrm{Mb}$ & SLCFR & F17-4 & $2497 m-2572 m$ \\
\hline & \multicolumn{2}{|l|}{ Puzzle Hole Fm } & SLCP & F11-2 & $2175 m-2397 m$ \\
\hline & \multicolumn{2}{|l|}{ Upper Graben Fm } & SLCU & F03-3 & $2547 m-2670 m$ \\
\hline & \multicolumn{2}{|l|}{ Middle Graben Fm } & SLCM & F03-3 & $2670 m-3090 m$ \\
\hline & & Middle Graben Sandstone Mb & SLCMS & F05-1 & $2628 m-2648 m$ \\
\hline & \multicolumn{2}{|l|}{ Lower Graben F m } & SLCL & F03-3 & $3090 m-3652 m$ \\
\hline
\end{tabular}

This sequence contains two major MFS, the Early Kimmeridgian 363 MFS which shows the first marine ingressions in the Terschelling Basin and the Late Kimmeridgian J66 MFS which coincides with the top of the Terschelling Sandstone Mb. (Fig. 5). The beginning of the Late Jurassic arid phase, marked by the Late Kimmeridgian Scitulus climate shift, correlates to the base Oyster Ground Claystone $\mathrm{Mb}$. Sequences 2 and 3 are relatively thick in the Terschelling Basin as compared to the Central Graben. Moreover, a hiatus occurs in the Central Graben, but deposition was continuous in the depocentre of the Terschelling Basin. The SEG data from well L06-02 clearly show a strong increase in 'Coastal Warm' elements (Fig. 5). This EcoGroup is normally present along the marine coast. However, their dominance suggests invasion of the lowland area. This is indicative of (very) arid conditions (Abbink et al., 2001).

\section{Sequence 3: late Early Portlandian - Ryazanian (Fig. 6)}

The base of Sequence 3 is dated as late Early Portlandian (Anguiformis Ammonite Chronozone) and the top as basal Valanginian ('base Cretaceous'). Within this sequence all other 'Late Jurassic' basins also came into existence and all previous deposits were overstepped. The Early Portlandian J73 MFS is represented in a large part of the Dutch offshore (Spiculite Mb. and correlative equivalents). The Early Ryazanian J76 MFS forms the base Clay Deep and Schill Grund Mbs. Within this sequence the Early Ryazanian Kochi climate shift ( \pm base Stortemelk Mb.) is a significant marker. Within Sequence 3, the arid phase ended, and the climate returned to wet, tropical conditions ('Wealden' facies) as indicated by the SEGs (Fig. 6; see also Abbink et al., 2001).

\section{Younger sequences}

Although not further discussed here, the base of the overlying sequence (4) is formed by a regional, overall Cretaceous transgression. All intermediate highs and non-marine areas show marine depositions from this time onward. Locally, the base of this sequence may be formed by a hiatus (Fig. 11).

\section{Potential oil and gas play prospects in the Dutch 'Late Jurassic'}

A play, in petroleum geological terms, consists of three essential elements: the source rock, the reservoir, and the seal. These elements can be mapped on their presence or absence but they 


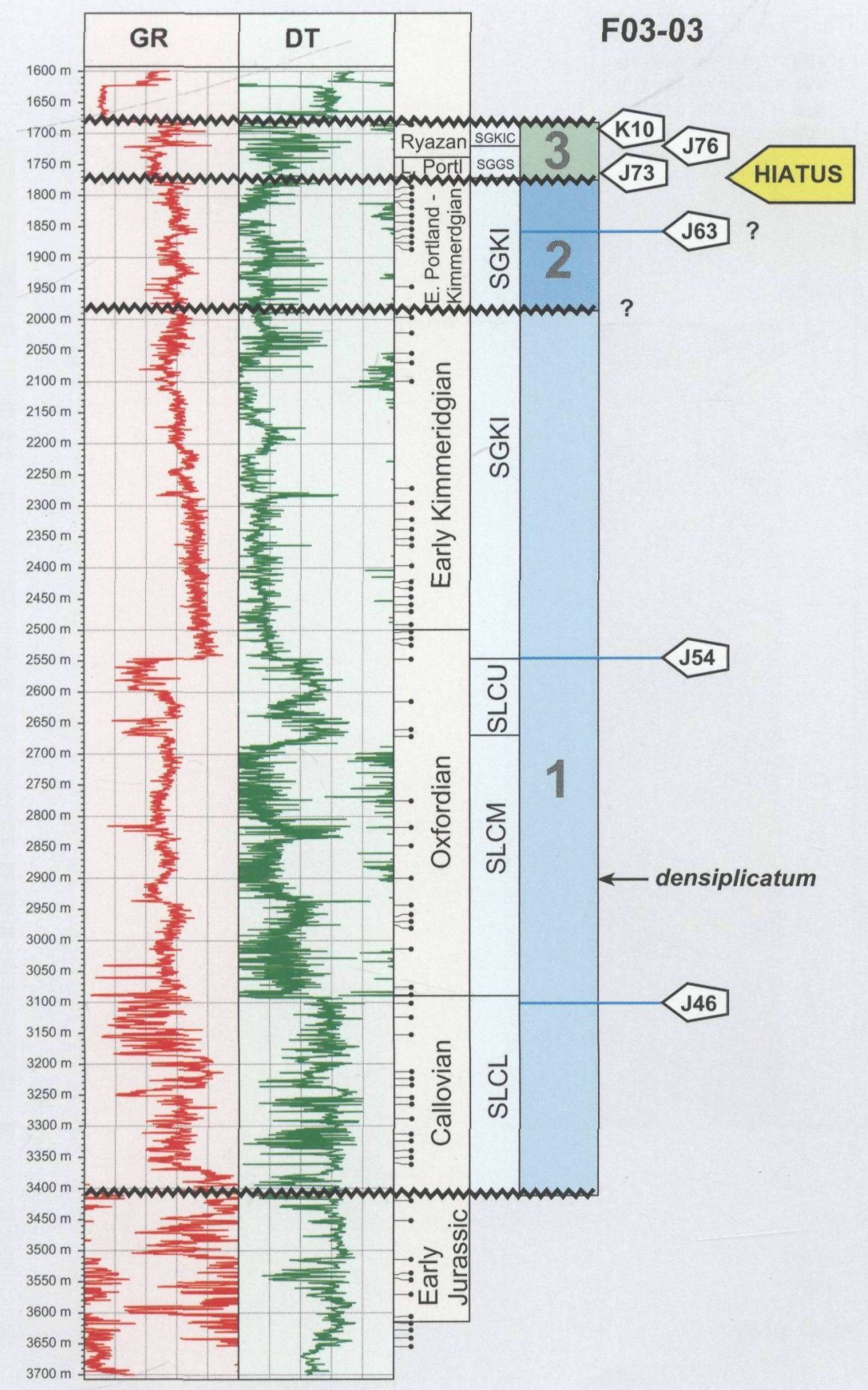

Fig. 4. Example of Sequence 1 in well F03-03 with major MFS (J numbers) and climate shifts.

may also be mapped in more detail. For example, the source rock maturity, or the reservoir thickness or quality can be mapped. Play mapping is a prerequisite for the understanding of the petroleum system in which the play-maps are integrated with timing of the various events such as structuration, maturation and migration.

In our study area the 'Late Jurassic' play is a proven play concept. Various fields (Table 1) are found with oil or gas accumulations in 'Late Jurassic' reservoirs. Hydrocarbon typing indicates that the oil is predominantly sourced from the Jurassic
Posidonia Shale and the gas from the Carboniferous. All fields listed in table 1 are structural closures such as four way dip closure on the top of a salt dome (F18-FA or L6-A) or a turtle back structure like F3-FB, although the structure of the latter field is considered to include a strat-trap component. In the following section, two different 'Late Jurassic' play types are described. 


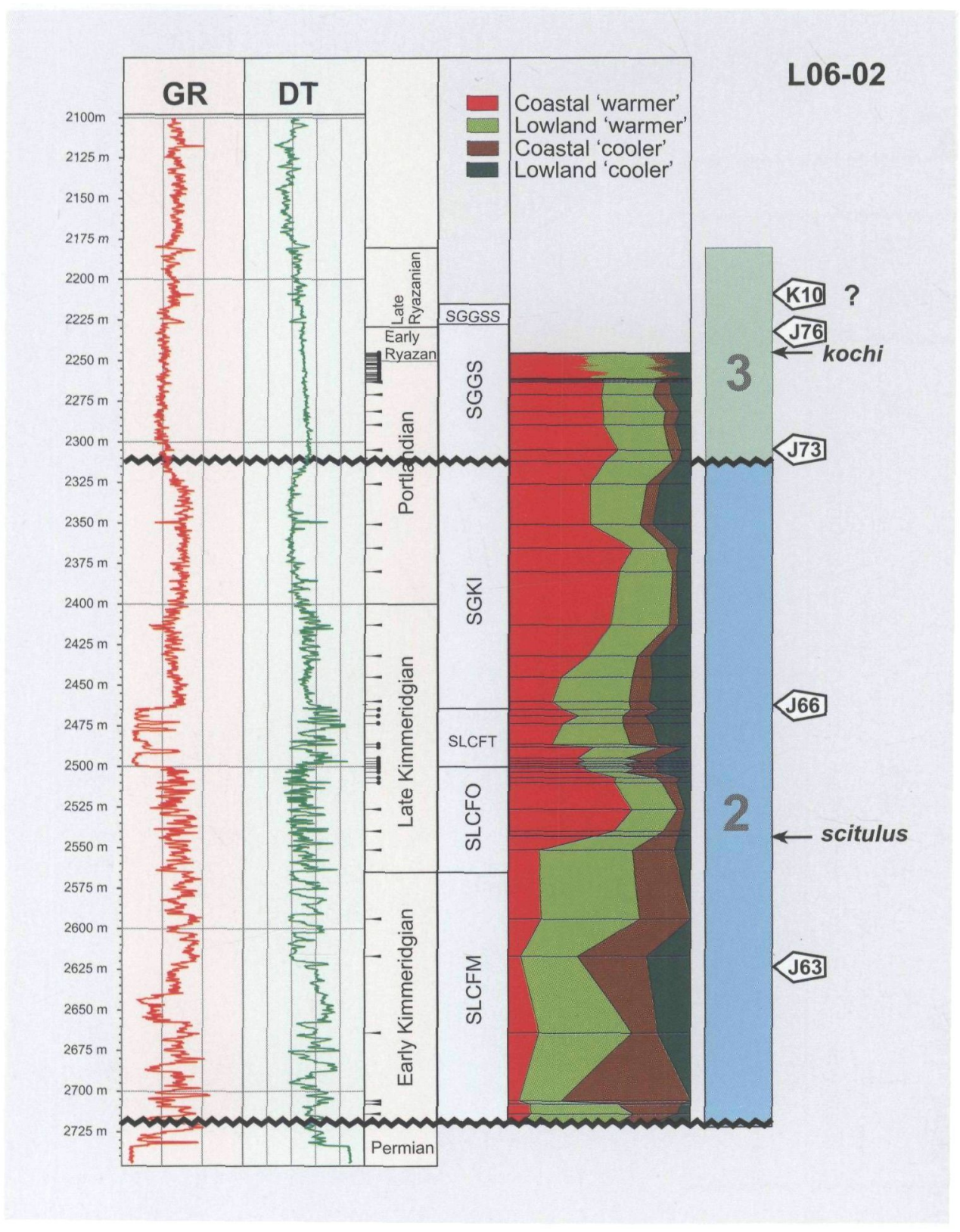

Fig. 5. Example of Sequence 2 in well L06-02 with major MFS (J numbers) and climate shifts.

\section{Paralic/fluvial Sequence 1 strat-trap play}

\section{Source rock}

The source rock for this play in case of oil is the Early Jurassic Posidonia Shale. Claystone intervals in the Kimmeridgian or the Ryazanian Clay Deep Formation may also contain source rock quality beds (from Lokhorst et al., 1998). The main source rocks for the gas accumulations in this play are the Carboniferous coals and bituminous shales. The migration route may be tortuous and long but is proven to be present because Carboniferous sourced gas is found above the regional Zechstein seal in the Jurassic-Cretaceous L6-A \& G16-A gas fields.
Seal

Seals for the Sequence 1 reservoirs in the oilfields in the study area (Table 1) are the Vlieland Claystone in a truncation trap configuration. In addition, clay intervals in Sequence 1 deposited under higher base-level or sea-level conditions may prove to be laterally extensive and may act as an intraformational seals (stratigraphic traps) for the intercalated channel sandstones. In general, the terrestrial and paralic clays within the Sequence 1 do not appear to possess a seal capacity for gas. Moreover, locally the sealing capacity may be low due to the nature of the claystones, possibly due to soil formation processes. This may have created a fine network of minor seal breaches which is presumed to act as the migration route for gas but, in general, not for oil. Oil seals may, therefore, be 


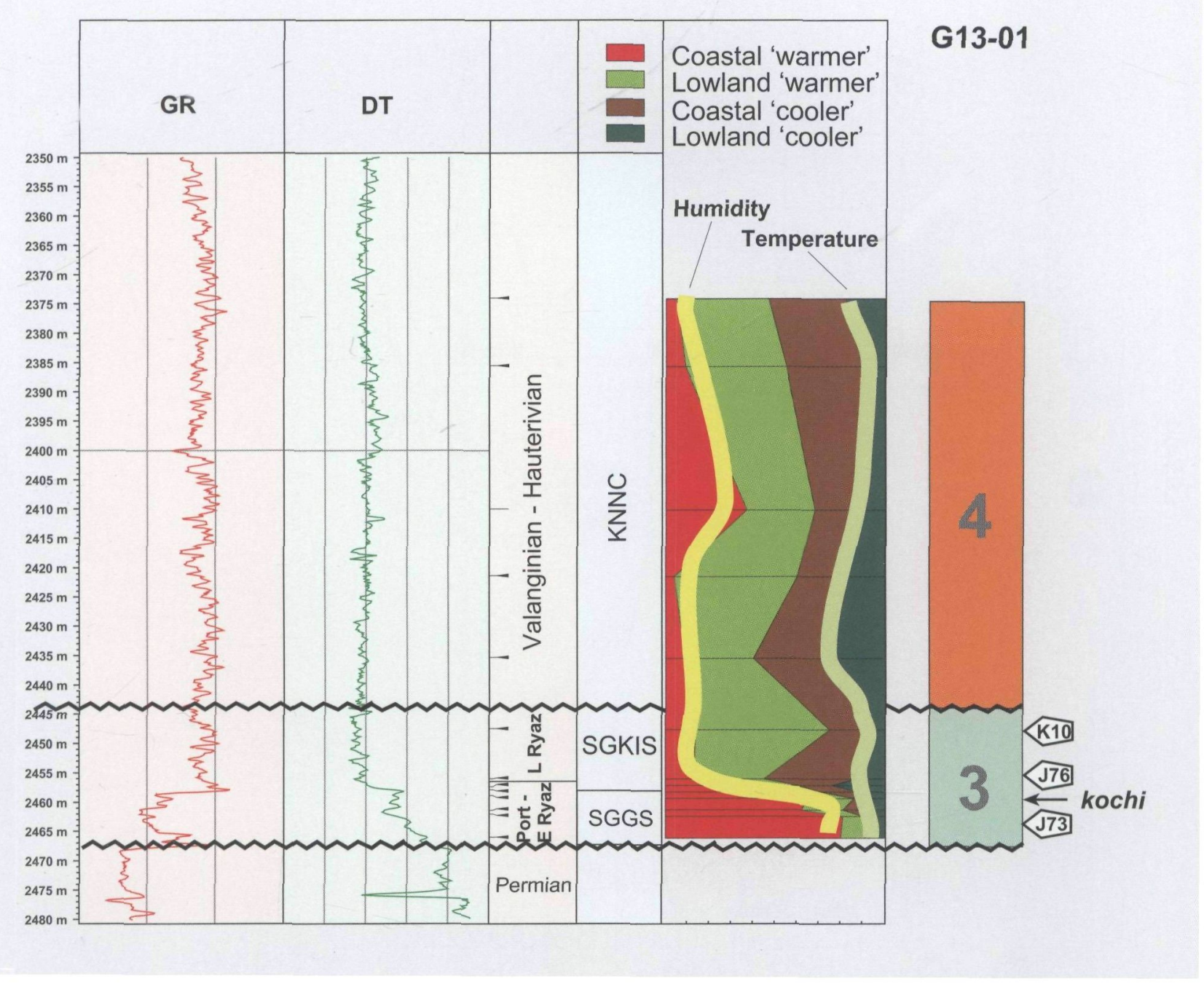

Fig. 6. Example of Sequence 3 in well G13-01 with major MFS (J numbers) and climate shifts. The SEG curves indicate the change from 'Late Jurassic arid phase' to the Early Cretaceous wet 'Wealden' conditions (yellow line).

formed by above mentioned clay prone intervals in the succession. The presence of stacked oil-water contacts in, for example, the L05-FA field indicates that claystones have a sealing capacity, and that stratigraphic traps occur in Sequence 1.

\section{Reservoir}

Sequence 1 comprises interbedded claystones and sandstones of non-marine to very shallow marine (lagoonal) origin. Correlation of the various sequences between wells based on well logs is rather difficult. An example of the classic log correlation between wells one based on the thick sandy intervals is shown in Figure 7 (correlation highlighted in yellow). However, integration of the biostratigraphical information and facies interpretation from cores provides a different picture. In particular, the SEG information provides a number of discrete, isochronous events. The Densiplicatum climate shift (after Abbink et al. 2001) is given in red (Fig. 7). The MFS are based on the Coastal/Lowland ratio (Fig. 7; green curve; see Abbink et al., 2004a, b). Sand bodies, stacked channel sandstones and tidal channels, appear discontinuous and are enclosed in floodplain and lagoonal clays with common soil horizons. The seismic facies of Sequence 1 is characterized by discontinuous reflectors (Fig. 8) which can be explained by the discontinuous nature of the Sequence 1 sandstones.

In Figure 9, a seismic time thickness map for the Dutch Central Graben is given. This relative thickness map approximates the thickness of Sequence 1 in the Dutch Central Graben. In the Terschelling Basin (Fig. 1), this map mainly reflects the thickness of Sequence 2 (Fig. 9). From the seismic time thickness map of Sequence 1 in the Dutch Central Graben (Fig. 9), it may be deduced that these highs were in late Jurassic times also highs, incipient highs or basin fringes. It may be concluded that the major fluviatile axes were situated in the lows between these highs and that the most sand prone interval of the paralic/fluvial Early and Middle Graben Formation will also be situated in the lows (Fig. 10). Almost all wells in the study area that penetrate Sequence 1 are situated on present day 


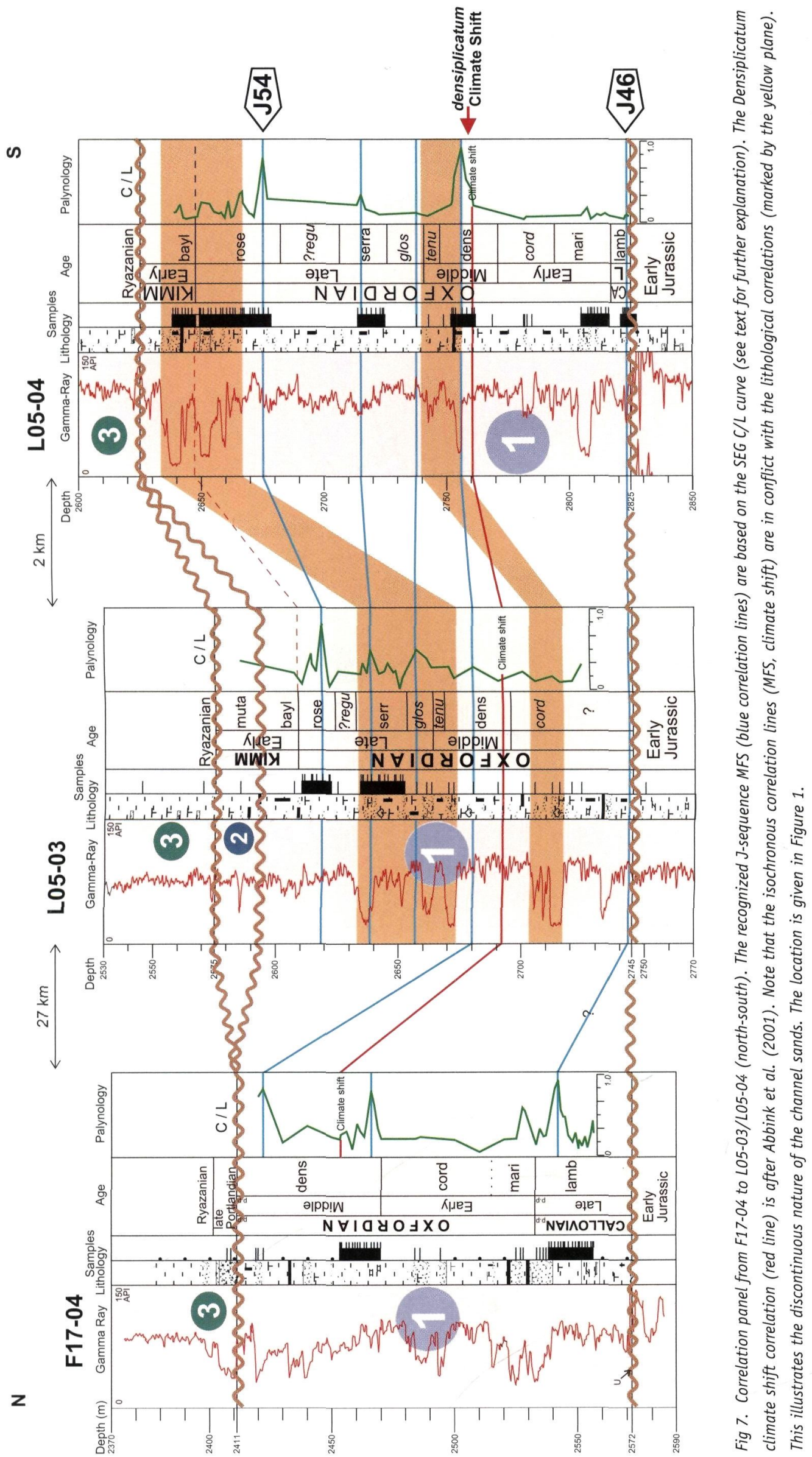


structural highs (Figs 1, 9) except for the wells F03 field. Although on a present day high (turtle back structure), the F03 oil field is situated in the basin axis in which an increased sand content is present (i.e. in the basin centre of Figure 10). This supports the concept that, during Sequence 1, more (most) sand was deposited in the central, deeper parts of the Dutch Central Graben along the major fluviatile axes.

\section{Concept and model for the Sequence 1 strat-trap play}

Figure 10 schematically shows the major play elements. The Posidonia Shale is underlying the presumed Sequence 1 reservoir interval. In the present day basin axis of the Central Graben, the Posidonia Shale is a good quality, mature oil source rock. When migrating upwards, the oil entered the Sequence 1 sediments and the channel sandstones acted as a favourable fairway. However, these sandstones are laterally discontinuous and are enclosed within claystones which may provide top and seat seal resulting in a stratigraphic trap in which the oil accumulates. The main play risk is the quality of the seal. The presence of oil accumulations up dip from the basin centre (e.g. L05-FA) with stacked oil-water contacts is considered support for the sealing quality of the claystones. However, it may be concluded that the oil passed the strat-trap. This may suggest the stattrap play lacks seal integrity in some cases. Alternatively, it may be concluded that the strat-trap is filled to spill point and excess oil bypassed the oil filled stacked channel sands.

\section{Shallow marine Sequence 3, Spiculite play}

\section{Source rock}

The Spiculite play is thought to be primarily a gas play but it could also be an oil play under the right conditions. The source rocks are the same as described in the section on the strattrap play.

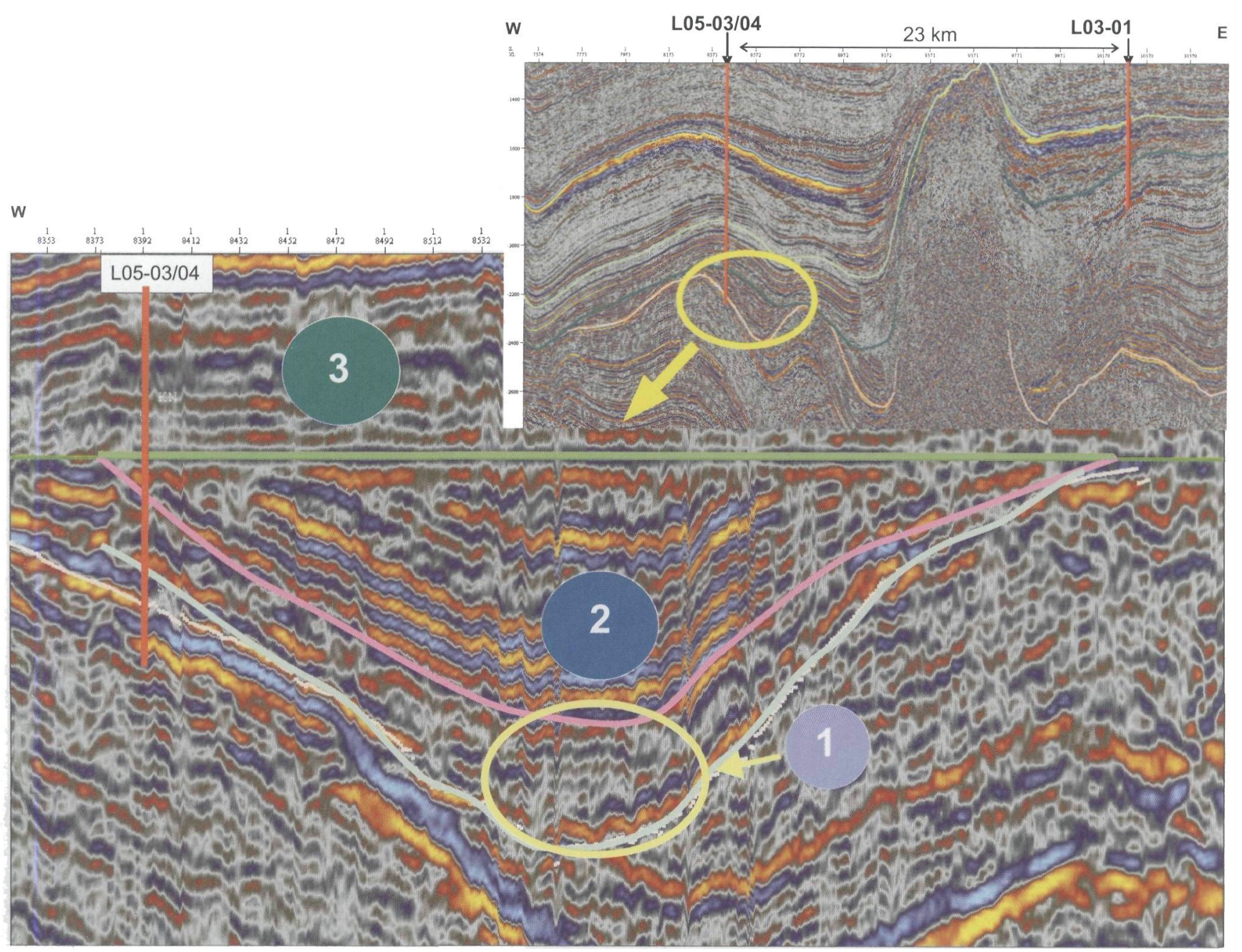

Fig. 8. Seismic profile of the L05-03/04 area towards LO3-01 (W-E) showing the overall view (right hand corner) and the details image (flattened on the base of Sequence 3; green line). The base of Sequence 1 is indicated with light green, and the base of Sequence 2 with pink. Sequence 1 thickens from the sides towards the centre of the syncline. Note the discontinuous (channel?) nature of the reflections compared to those of Sequence 2. The location is given in Figure 1 . 


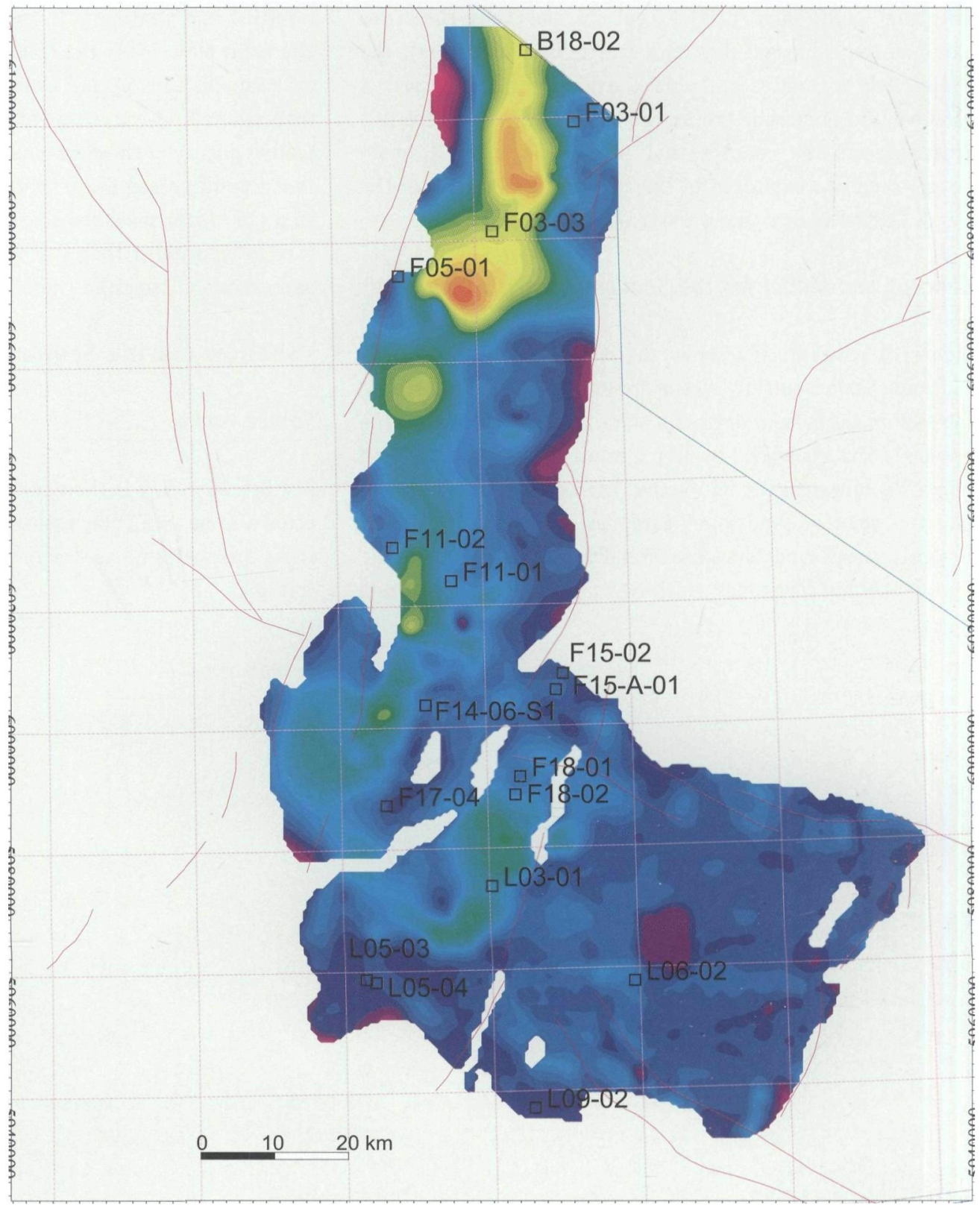

Fig. 9. Seismic time thickness map approximating the relative thickness of Sequence 1 in the Central Graben and the relative thickness of Sequence 2 in the Terschelling Basin (red is thickest; dark blue is thinnest). Note that this map based on a relatively low dataset, and it is for explanatory purposes only.

\section{Spiculite reservoir}

The main focus of this section is to present ideas on the distribution of the Spiculite reservoir. This is done by proposing a conceptual model based on wells F18-01 and L03-01 (Fig. 11).

The reservoir of this play comprises the sandstones of the Spiculite Member of the Late Jurassic Scruff Greensand Formation (Sequence 3). The name Spiculite Member is given to the unit because of the abundance of sponge spicules in the sediment; in some cases spicules make up the bulk of the framework forming a bioclastic sandstone. Spicules are the skeletal elements of sponges. The spicules in the sediments of Spiculite Member are determined to be mona-, tri- and possibly tetraxons of amorphous silica and are interpreted to be the remnants of the siliceous sponges (Demospongia).

Regional correlation of the Spiculite Member shows remarkable thickness variations (Figs 11, 12). The Spiculite Member in the F18-01 well is about 40m whereas in well L03-01 it is about three times thicker. Biostratigraphical data proves that in both locations the time span represented by the sediments is the same. In both wells no erosion of the top of the formation occurred nor is the basal part missing due to onlap. The thickening observed in the wells is also visible on seismic (Fig. 12). From F18-01 situated on the top of a salt dome, the Spiculite Member thickens towards L03-01. Hence, the section in F18-01 is considered condensed relative to L03-01. 


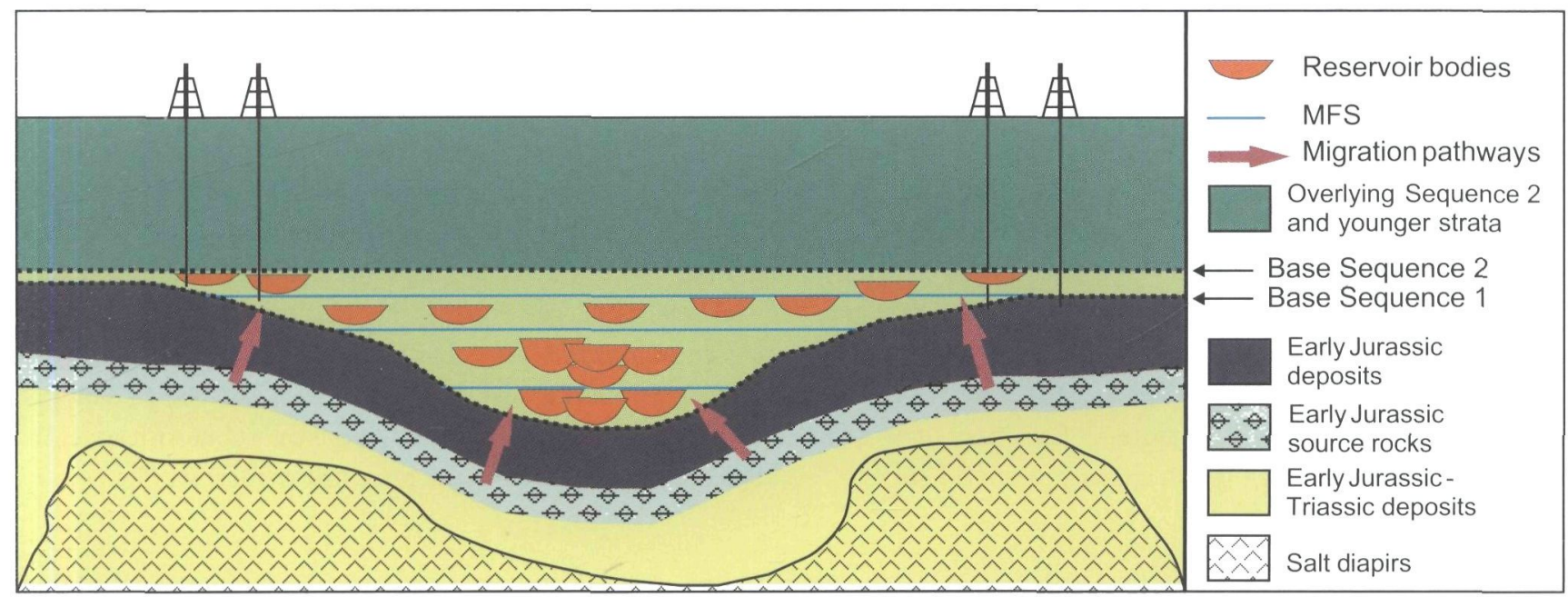

Fig. 10. Schematic diagram of the Sequence 1 strat-trap play. The diagram runs across the main fluviatile graben axis. Schematically, the wells located on the left may represent the L05-03/04 wells.

Cores from the Spiculite Member of the two wells were described in detail (Werver, 1996). The sediments comprise intensely bioturbated, fine grained, glauconitic sandstones and clayey sandstones with no sedimentary structures except for ichnofossils traces (Fig. 13). The intense bioturbation and the presence of a fair amount of glauconite in the sediment are the result of low sedimentation rates in a shallow marine environment (0din et al., 1981). Remarkable is the difference in clay content (observed macroscopically in cores as well as in thin sections (Figs 13, 14). In F18-01, it is relatively low compared to L03-01. A detailed depositional environment interpretation was made using ichnofossil associations (Fig. 13). This indicates that the depositional environment of F18-01 is predominantly offshore to shoreface whereas an open marine shelf environment is interpreted in L03-01. This interpretation is in line with the difference in clay content. Note the change in amplitude on the seismic section (Fig. 11) of the top Spiculite which hints on laterally varying impedance contrast. This may be due to lithology effects or be an indication of a porosity trend.

Qualitative petrographical evaluation of a series of thin sections from the cores of both wells confirmed the macroscopic observations above and revealed additional differences (Fig. 14):

- The content of sponge spicules in F18-01 is visibly higher than in L03-01.

- The amount of glauconite grains in L03-01 appears to be higher than in F18-01.

- Visible porosity in F18-01 is high whereas in L03-01 visible porosity is almost non-existent.

- In F18-01 a fair amount of the sponge spicules were dissolved resulting in a high percentage of mouldic pores. On the other hand primary porosity is reduced due to plugging with microcrystalline quartz cement, thus creating an inverse framework. In the thin sections of L03-01 visible porosity is low and sponge spicules can be recognized as framework grains.
The resulting reservoir properties of the two facies are remarkably different (Figs 14, 15). F18-01 shows excellent reservoir quality both in porosity and permeability whereas in L03-01 the permeability is very low (Fig. 15).

\section{Concept and model for the Spiculite reservoir location and quality}

The abundance of siliceous sponge reefs occurring in the Late Jurassic which appears to be quite unique phenomena (Kiessling et al., 1999). Siliceous demosponges rarely are preserved as they disintegrate when deceased, leaving only their skeletal elements, the spicules, behind. Demosponges are active filter feeding organisms consuming predominantly nannoplankton, mainly bacteria. As the abundance of bacteria decrease with depth this class of sponges can be found in shallow marine (30 - $90 \mathrm{~m}$ ) depositional environments. Demosponges are sensitive to sediment input because sediment particles clog up their inhalant pores (Leinfelder et al., 1996). The Spiculite of F18 and L3 can be interpreted bearing this information in mind.

The high concentration of spicules can be explained by a sponge bloom. The Late Eocene biosiliceous, sponge rich sediments of South-western Australia are thought to be an analogue (Gammon et al., 2000). The sediments seen in F18-01 are similar to the pure spiculite, Sp2, facies and the sediments of L03-01 fit better in the muddy spiculite ( $\mathrm{Sp} 1$ ) facies of Gammon et al. (2000). Gammon et al. (2000) explained the extraordinary bloom of siliceous sponges by proposing an semi enclosed marine environment where influx of nutrient rich (including silica) waters entered this environment from the hinterland. The semi-enclosed nature of the depositional area prevented the silica from being diluted or buffered directly by 'open marine' or oceanic waters.

During 'Sequence 3 ' the southern part of the Central Graben had an elongated nature. Local seafloor topography was created 
by incipient doming of the Zechstein salt. This basin configuration can be regarded as a semi enclosed marine depositional area where mixing with open marine waters was retarded (Fig. 16). A relative sea-level high encroached the landmass. This reduced the gradient and the drainage area of the fluvial system resulting in a low sediment input of predominantly fine grained sediments. The warm climate with occasional rainfall favoured chemical weathering, releasing many nutrients including silica. Additionally the existence of a volcano in this area (Mijnlieff, 2001), active in Late Jurassic times, may have added extra nutrients to the system, favouring growth of sponges or the bacteria on which sponges feed (Fig. 16).
In this shallow sea, seafloor highs, (incipient doming or alternatively by tilted fault blocks) were sites were the hydrodynamic energy was relatively high compared to neighbouring lows. At these sites clear water was predominant because clay bypassed and was trapped in relatively low energy sites. Submarine 'highs' were therefore favourable sites for sponge growth. As they bloomed, died and disintegrated their framework elements, the sponge spicules, were released into the environment and were deposited nearby. The concentration of spicules is thus highest close to the high and becomes diluted away from these localities. During the time of deposition of the Spiculite, these paleo-highs remained shallow marine because
Fig. 11. Correlation panel from well F18-01 to L03-01 illustrating the thickness change of the Spiculite and Sequence 3. Sequence 3 sits between the ' 3 ' marker and the blue KNNC marker (the $3 a$ and $3 b$ markers are intra sequence markers). The Spiculite sits between correlation lines SGGSP (Scruff Group Greensand Spiculite Member) and SGGSS (Scruff Group Greensand Stortemelk Member) and is highlighted in blue.

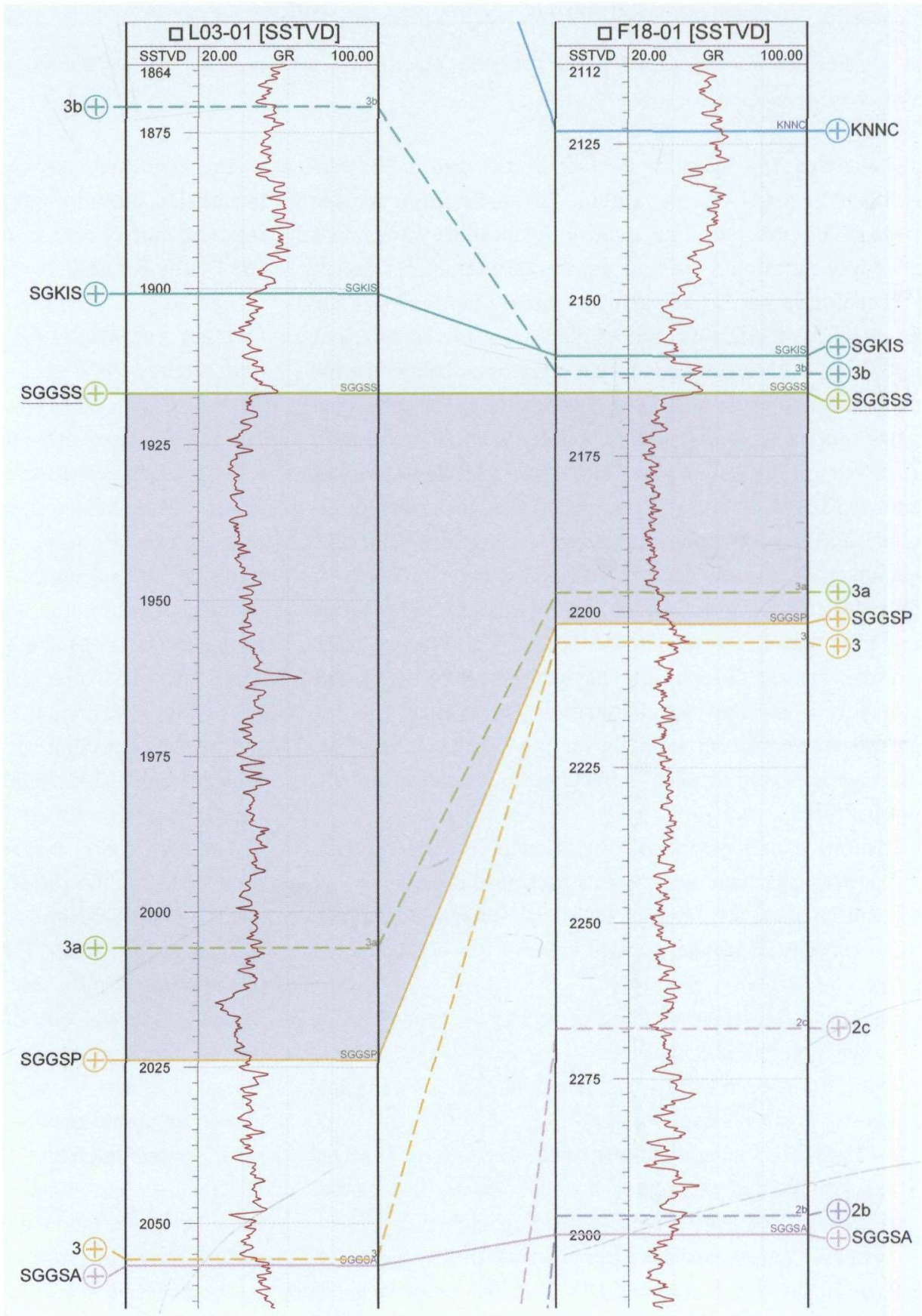




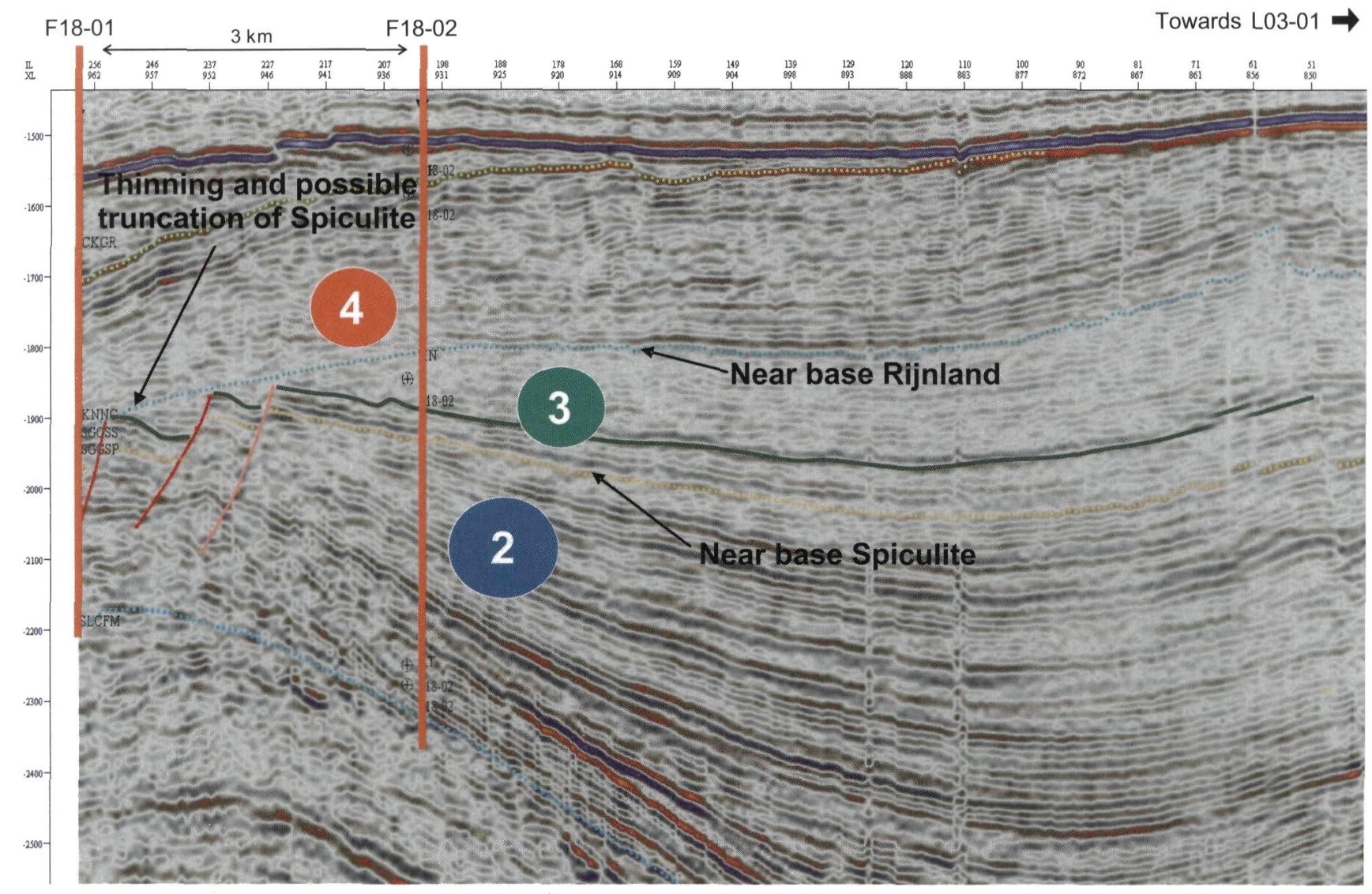

Fig. 12. Seismic section from well F18-01 towards L03-01. Yellow dotted line approximates the base of the Spiculite and is equivalents, the green line is the base of Sequence 3, the dotted light blue line is the base of Sequence 4. Note the dimming of the amplitudes from the left to the right side of well F18-02.
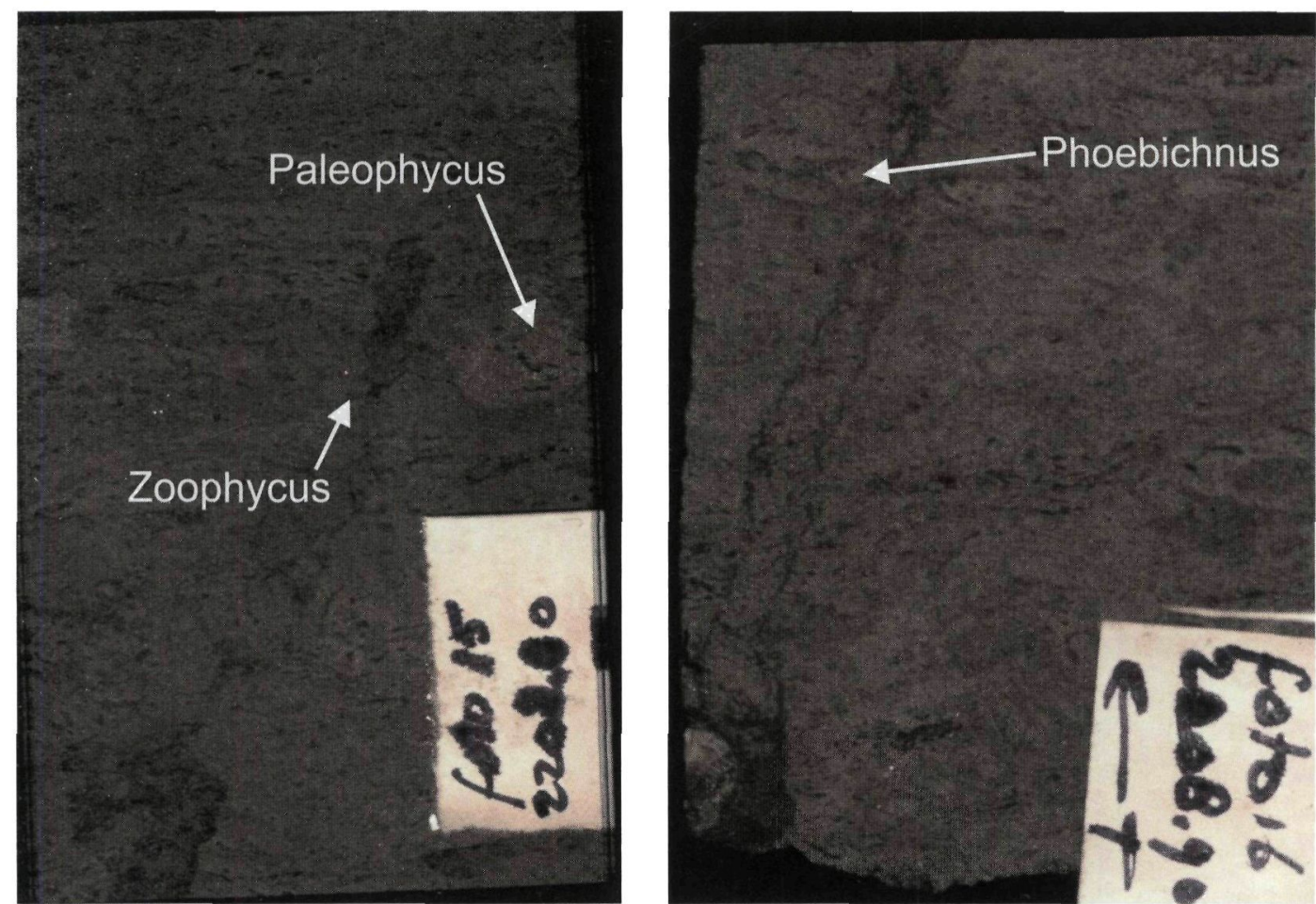

Fig. 13. Core photographs from well F18-01 (2208.80 $\mathrm{m}$ and $2208.90 \mathrm{~m})$ showing the typical, thoroughly bioturbated finegrained sandstones of the Spiculite. (Photo's courtesy of 0 . Werver). 
F18-01

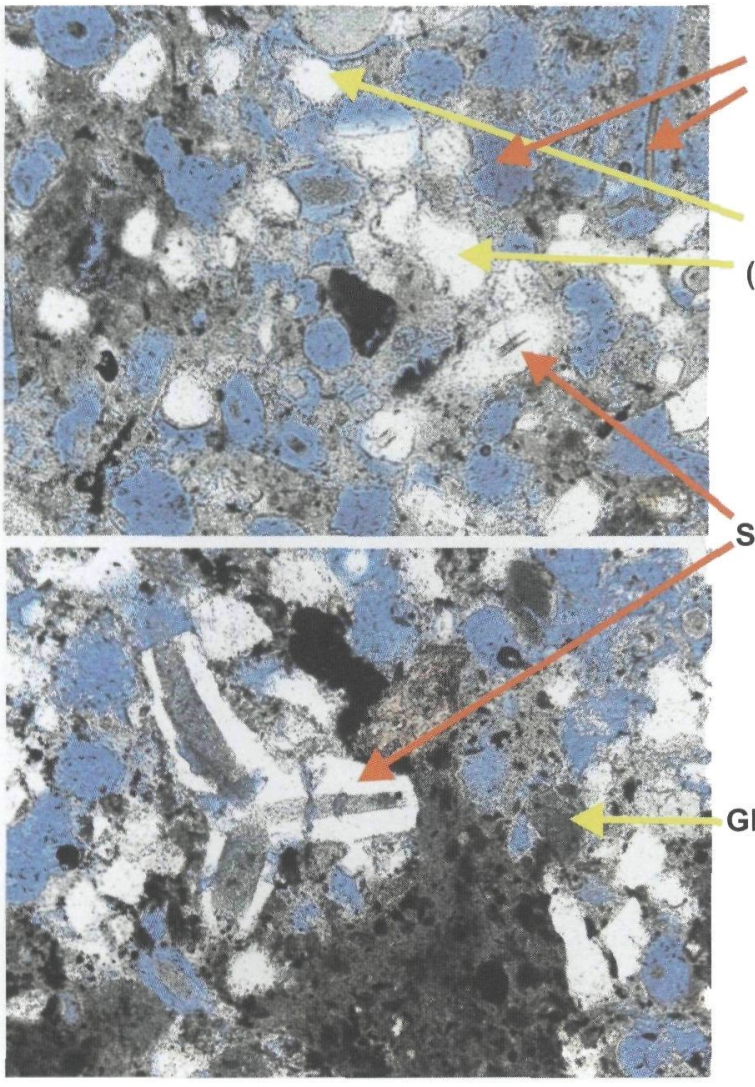

L03-01

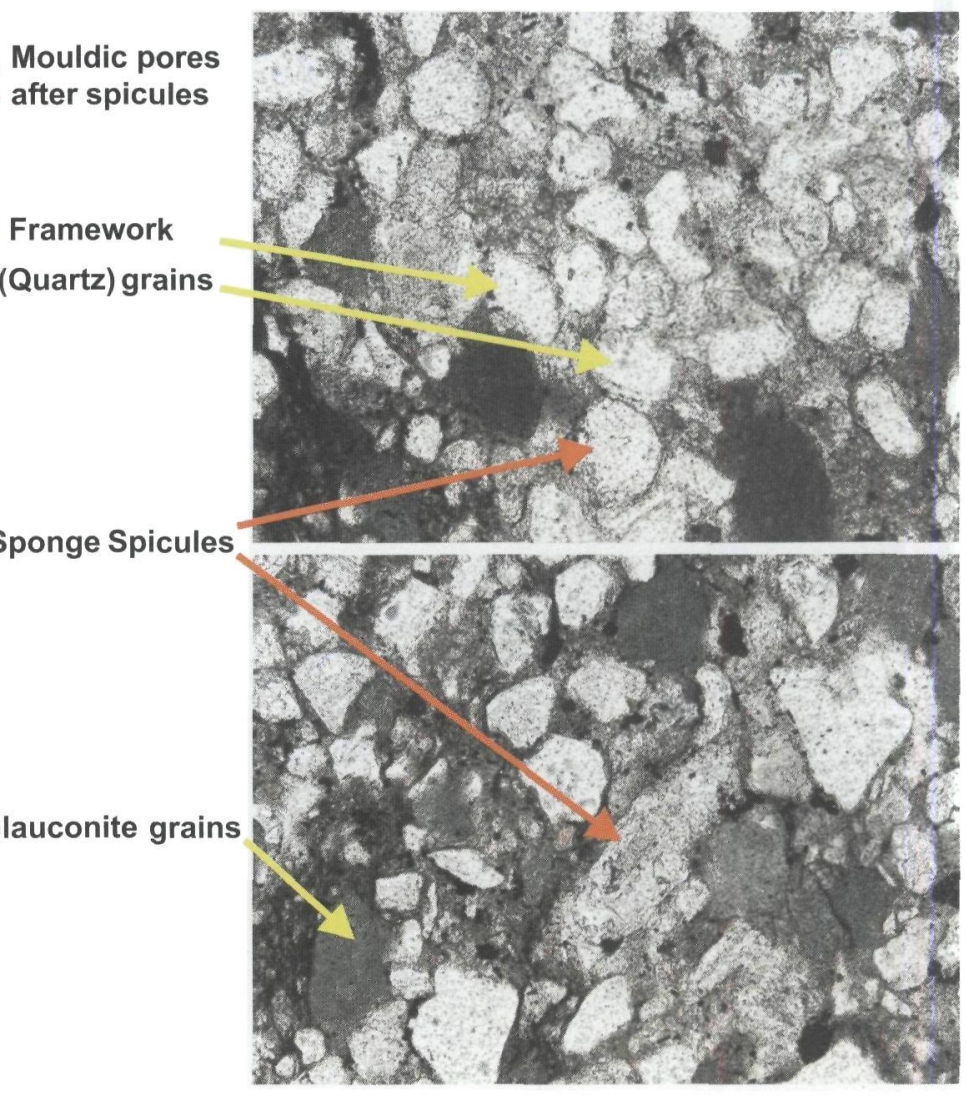

Fig. 14. Photomicrographs of thin sections of core samples from F18-01 (left) and L03-01 (right). The F18-01 sample indicates shallow marine and relative high energy conditions. The L03-01 sample indicates slightly less shallow marine and relatively low energy conditions.

of continuous salt movement while the surrounding areas subsided creating extra accommodation space. This resulted in a sediment pile reduced in thickness (but sandy because of the winnowing) on the highs compared to off-high positions.

Further salt doming in combination with a relative sea-level low resulted in the sub-aerial exposure and erosion of, especially, the basin highs at the base of Sequence 4 (base Rijnland Group; Fig. 12). The sub-aerial exposure is evidenced by a hard ground, a hematite cemented zone with mouldic pores, as seen in e.g. the well L09-02 (Van Adrichem Boogaert \& Kouwe, 1993). In well F18-01, meteoric waters caused leaching of fragile framework during sub-aerial exposure resulting in the inverse framework (Fig. 14).

\section{Seal and structure}

The seal of the Spiculite play can be the overlying claystones of the Kimmeridge Claystone Formation (either the from Clay Deep or the Schill Grund Member). The sealing capacity of these claystones is limited because of the occasional presence of sand stringers. The ultimate seal for both oil and gas is the Vlieland Claystone. At the base of the Vlieland Claystone an unconformity is present which may, locally, cut as deep in the underlying strata as the reservoir sandstones of the Spiculite play, removing the overlying non-reservoir horizons or waste zones (Fig. 12). Possible trap configurations of this play include: - a four way dip closure with the reservoir truncated and sealed by the Vlieland Claystone on top of a salt dome;

- a truncation trap configuration on the flank of a dome with the reservoir sealed by the Vlieland Claystone.

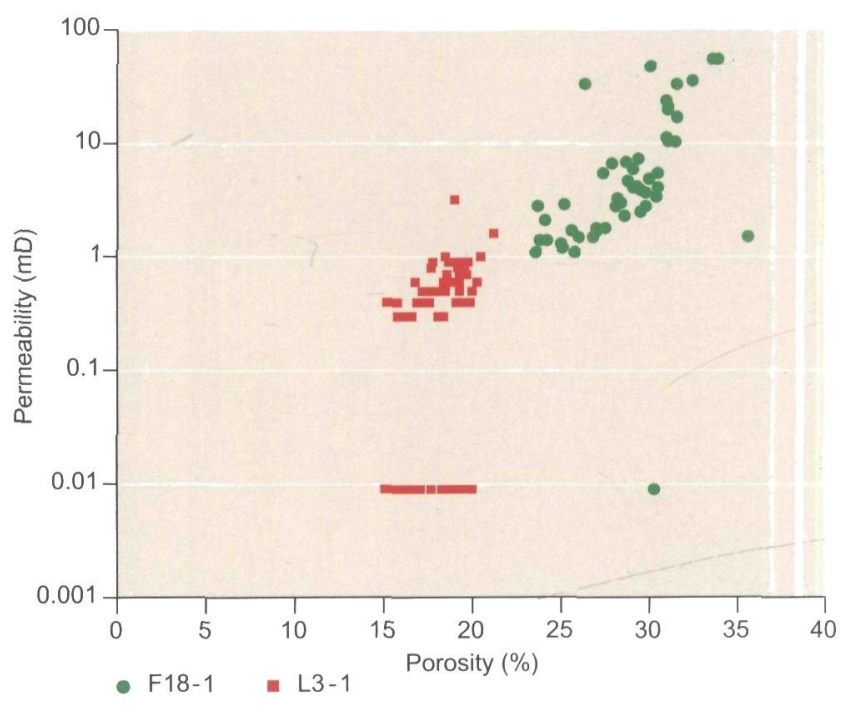

Fig. 15. Porosity-permeability cross-plot of wells F18-01 and L03-01. 


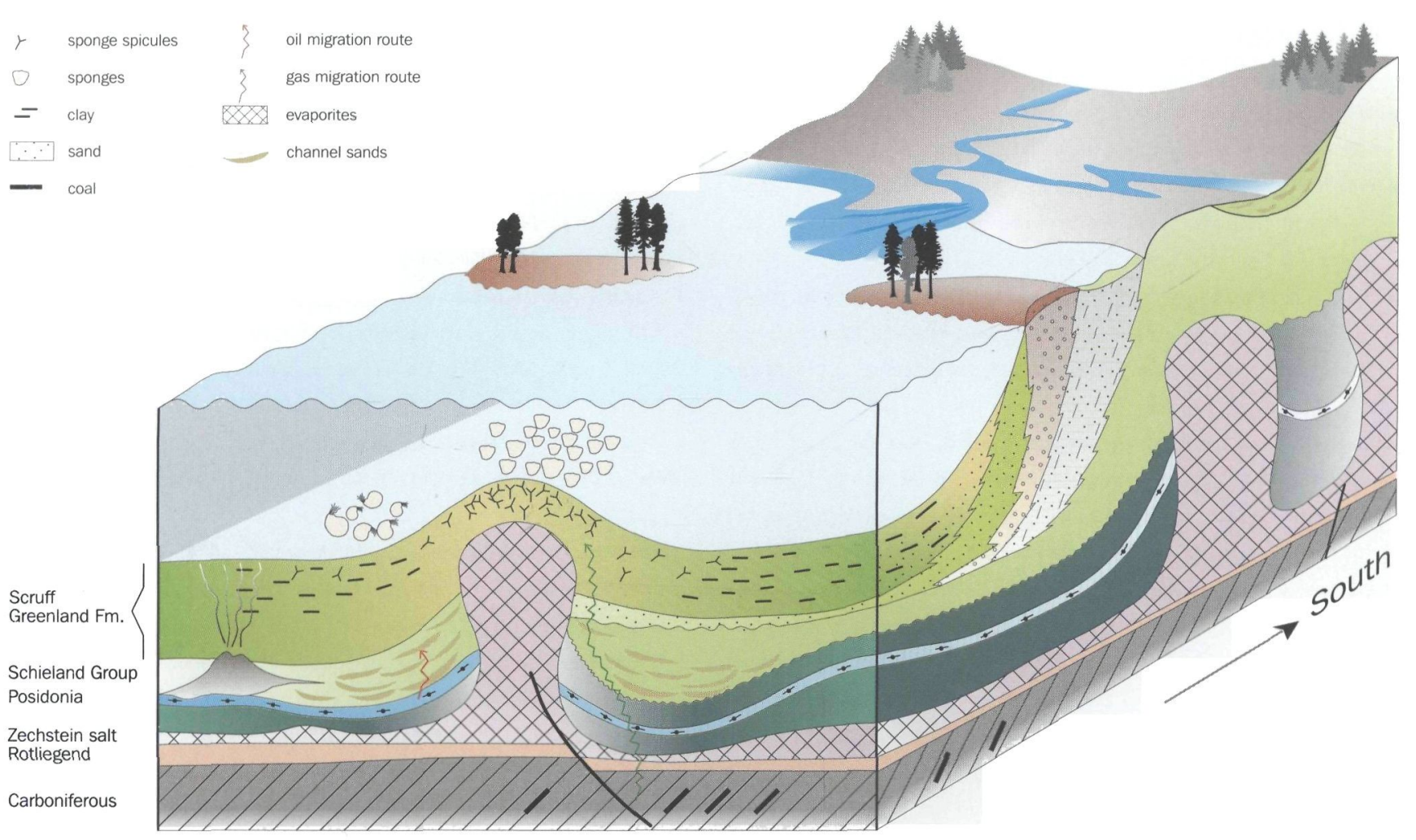

Fig. 16. Schematic diagram of the Spiculite (Sequence 3) play.

All elements for the play in the F18-01 location are present: good reservoir, gas in the system and a seal present. Only the structure at top reservoir is lacking. The seal, near base Rijnland, shown in Figure 12 is not in a trap configuration. Prospects may be defined using the reservoir distribution concept together with a top reservoir map and a base Cretaceous structure map. When drilled this possibly may result in a field as, for example, the F3-FA field.

\section{Conclusions}

During the 'Late Jurassic' a complex geological setting developed in the Dutch Northern Offshore. Within this setting three distinct stratigraphic sequences can be recognized. These sequences are punctuated by, at least, two significant MFS per sequence. Each sequence has its own, relatively unique, geological history. These sequences can be correlated with major changes in sea level and climate and are bounded by well defined dis- and unconformities.

Within sequence 1 a possible target for exploration may be channel sandstones deposited in the basin axis. They are presently concentrated in the structural lows and, therefore, this play relies on a stratigraphic trap configuration.

Within Sequence 3, the Spiculite sandstone is the play. The reservoir sands were deposited in a semi-enclosed marine environment where subtle seafloor topography, low sediment input and, in particular, nutrient conditions were favourable factors for preferential growth of siliceous sponge reefs. The accumulation of the spicules on the site of the reef produces an excellent bioclastic sandstone reservoir. Later dissolution of the spicules due to percolating (meteoric) water at the time of the Sequence 4 sequence boundary further enhanced the reservoir quality.

The integrated approach with the use of high resolution biostratigraphic, sedimentological, lithological, paleoenvironmental and paleoclimatic data enables the reconstruction of the geological history. In particular, the integration of all tools to reconstruct the 'Late Jurassic' earth has significant impact on the exploration models.

\section{Acknowledgements}

This article is based on a study carried out for Energie Beheer Nederland B.V. which we acknowledge for their financial support and permission for publication. TNO is thanked for additional financial and material support. Onno Werver is thanked for his kind cooperation. Susan Kerstholt, Waldemar Herngreen and Rob Van Eijs are thanked for their support. Theo Wong, Kees van der Zwan, Gordon Forbes and an unknown reviewer are thanked for constructive remarks. 


\section{References}

Abbink, O.A., 1998. Palynological investigations in the Jurassic of the North Sea region. LPP Contribution Series 8: 192 pp.

Abbink, O.A., Targarona, J., Brinkhuis, H. \& Visscher, H., 2001. Late Jurassic to earliest Cretaceous palaeoclimatic evolution of the Southern North Sea. Global and Planetary Change 30: 231-256.

Abbink, O.A., Van Konijnenburg - Van Cittert, J.H.A. \& Visscher, H., 2004a. A Sporomorph Ecogroup Model for the Northwest European Jurassic - Lower Cretaceous I: concepts and framework. Netherlands Journal of Geosciences 83: 17-28.

Abbink, O.A., Van Konijnenburg-Van Cittert, J.H.A., Van der Zwan, C.J. \& Visscher, H., 2004b. A Sporomorph Ecogroup Model for the Northwest European Jurassic - Lower Cretaceous II: application to an exploration well from the Dutch North Sea. Netherlands Journal of Geosciences 83: 79-90.

DeGraciansky, P.-C., Hardenbol, J., Jacquin, T., Vail, P.R. \& Farley, M.B., 1999. Jurassic sequence chronostratigraphy/biochronostratigraphy. In: De Graciansky et al. (eds): Mesozoic-Cenozoic Sequence Stratigraphy of European Basins. Special Publication of the Society of Economists, Paleontologists and Mineralists, 60: Charts 6 and 7 .

Duxbury, S., Kadolsky, D. \& Johansen, S., 1999. Sequence stratigraphic subdivision of the Humber Group in the Outer Moray Firth (UKCS, North Sea). In: Jones, R.W. \& Simmons, M.D. (eds): Biostratigraphy in Production and Development Geology. Geological Society London, Special Publications 152: $23-54$.

Gammon, P.R. \& James, N.P., 2001. Palaeogeographical influence on late Eocene biosiliceous sponge-rich sedimentation, southern Western Australia. Sedimentology 48: 559-584.

Gammon, P.R., James, N.P. \& Pisera, A., 2000. Eocene spiculites and spongolites in south-western Australia: Not deep, not polar, but shallow and warm. Geology 28: 855-858.

Gradstein, F., Ogg, J. \& Smith, A., 2004. A Geologic Time Scale 2004. Cambridge University Press (Cambridge): 589 pp.

Haq, B.U., Hardenbol, J., \& Vail, P.R., 1988. Mesozoic \& Cenozoic chronostratigraphy and cycles of sea level change. In: Wilgus, C. K., Hastings, B. S. et al. (eds): Sea Level Changes; An Integrated Approach. Special Publication of the Society of Economists, Paleontologists and Mineralists 42: 71-108.

Herngreen, G.F.W. \& Wong, Th.E., 1989. Revision of the 'Late Jurassic' stratigraphy of the Dutch Central North Sea Graben. Geologie \& Mijnbouw 68: 73-105.

Herngreen, G.F.W., Kerstholt, S.J. \& Munsterman, D.K., 2000. CallovianRyazanian ('Upper Jurassic') palynostratigraphy of the Central North Sea Graben and Vieland Basin, the Netherlands. Mededelingen Nederlands Instituut voor Toegepaste Geowetenschappen TN0 63: 1-99.

Jacquin, T., Dardeau, G., Durlet, C., DeGraciansky, P.-C. \& Hantzpergue, P., 1999. The North Sea cycle: an overview of 2nd order Transgressive/ Regressive facies cycles in Western Europe. In: De Graciansky et al. (eds): Mesozoic-Cenozoic Sequence Stratigraphy of European Basins. Special Publication of the Society of Economists, Paleontologists and Mineralists 60: 445-466.

Kiessling, W., Flügel, E. \& Golonka, J., 1999. Paleoreef maps: evaluation of a comprehensive database on Phanerozoic reefs. American Association of Petroleum Geologists Bulletin 83: 1552-1587.
Leinfelder, R.R., Werner, W., Nose, M., Schmid, D.U. Krautter, M., Laternser, R. Takacs, M \& Hartmann, D., 1996. Paleoecology, growth Parameters and Dynamics of coral, Sponge and Microbilite Reefs from the Late Jurassic. In: Reitner, J., Neuweiler, F. \& Gunkel, F. (eds): Global and Regional Controls on Biogenic Sedimentation. I Reef Evolution. Research reports - Göttinger Arbeiten zur Geologie und Paläontologie, Sonderband: 227-248.

Lokhorst, A. (ed.), 1998. Northwest European Gas Atlas - composition and isotope ratios of natural gases. Netherlands Institute of Applied Geoscience TN0 report, Haarlem, the Netherlands. ISBN 90-72869-60-5.

Mijnlieff, H.F., 2001. Top Pre-Permian distribution map \& some thematic regional geologic maps of the Netherlands. ICCP conference August 2003 , Utrecht, the Netherlands: poster presentation.

Odin, G.S. \& Matter, A., 1981. De Glauconarium Origine. Sedimentology 28: 611-641.

Partington, M.A.P., Copestake, P., Mitchener, B.C. \& Underhill, J.R., 1993. Biostratigraphic correlation of genetic stratigraphic sequences in the Jurassic - lowermost Cretaceous (Hettangian - Ryazanian) of the North Sea and adjacent areas. In: Parker, J.R., (ed.): Petroleum Geology of Northwest Europe: Proceedings of the 4th Conference: 371-386.

Partington, M.A.P., Mitchener, B.C., Milton, N.J. \& Fraser, A.J., 1993a. Genetic sequence stratigraphy for the North Sea Late Jurassic and Early Cretaceous of the North Sea: distribution and prediction of KimmeridgianLate Ryazanian reservoirs in the North Sea and adjacent areas. In: Parker, J.R. (ed.): Petroleum Geology of Northwest Europe, Proceedings of the 4th Conference: $347-370$.

Riding, J.B. \& Thomas, J.E., 1992. Dinoflagellate cysts of the Jurassic System. In: Powell, A.J. (ed.): A Stratigraphic Index of Dinoflagellate Cysts: 7-98.

Rioult, M, Dugué, O., Jan du Chêne, R., Ponsot, C., Fily, G., Moron, J. \& Vail, P.R., 1991. Outcrop Sequence stratigraphy of the Anglo-Paris basin Middle to Upper Jurassic (Normandy, Maine, Dorset). Bulletin des Centres de Recherches Exploration-Production Elf-Aquitaine 15: 101-194.

Underhill, J.R. \& Partington, M.A.P., 1993. Jurassic thermal doming and deflation in the North Sea: implications of sequence stratigraphic evidence. In: Parker, J.R. (ed.): Petroleum Geology of Northwest Europe: Proceedings of the 4th Conference: $337-345$.

Vail, P.R., Audemard, F., Bowman, S.A., Eisner, P.N. \& Perez-Cruz, C., 1991. The stratigraphic signatures of tectonics eustacy and sedimentology - an overview. In: Einsele, G. et al. (eds): Cycles and events in stratigraphy: 250-275.

Van Adrichem Boogaert, H.A. \& Kouwe, W.L.F.P., 1993. Stratigraphic nomenclature of the Netherlands, revision and update by RGD and NOGEPA. Mededelingen Rijks Geologische Dienst Nieuwe Serie 50.

Werver, 0., 1996. Ichnofauna in relation to the depositional environment of Jurassic and Cretaceous sediments in the Netherlands. Part I: Atlas of Ichnofauna. Stichting Educatie Centrum Ammonietenhoeve. ISBN 90-803304-1-8.

Werver, 0., 1997. Ichnofauna and flora in relation to their environment of sediments in the Central Graben, Netherlands Offshore. Environmental interpretation based on trace fossils from the Upper Jurassic - Lower Cretaceous. Stichting Educatie Centrum Ammonietenhoeve. ISBN 90-803304-1-8

Ziegler, P.A., 1990. Geological Atlas of Western and Central Europe, 2nd and completely revised edition, Shell International Exploration and Production B.V., the Hague, Geological Society Publishing House (Bath): 239 pp. 